\title{
Do alpine macroinvertebrates recover differently in lakes and rivers after alien fish eradication?
}

\author{
Rocco Tiberti ${ }^{1, *}$ and Stefano Brighenti ${ }^{2,3}$ \\ ${ }^{1}$ DSTA, Dipartimento di Scienze della Terra e dell'Ambiente, Università di Pavia, Via Ferrata 9, 27100 Pavia, Italy \\ ${ }^{2}$ Dipartimento di Ingegneria Civile, Ambientale e Meccanica, Università degli Studi di Trento, Via Mesiano 77, 38123 Trento, Italy \\ 3 Sustainable Ecosystems and Bioresources Department, Fondazione E. Mach, IASMA Research and Innovation Centre, \\ Via E. Mach 1, 38010 San Michele all'Adige, Trento, Italy
}

Received: 16 April 2019 / Accepted: 29 July 2019

\begin{abstract}
Introduced fish can have detrimental effects on native biota inhabiting alpine freshwaters with the extent of their impact depending on variables such as habitat features. The present study aims to compare the recovery of macroinvertebrate communities following a fish eradication campaign in a mountain lake (Lake Dres, $2087 \mathrm{~m}$ a.s.l., Western Italian Alps) and its inflowing and outflowing streams. All fish were removed using mechanical methods, not producing side-effects for macroinvertebrates. During eradication, the lake community, which had previously been greatly affected, rapidly recovered to levels typical of neverstocked lakes. Stream communities, however, were apparently not impacted by fish populations and remained relatively stable, proving their greater capacity to withstand fish presence. The abundance of spatial refugia and invertebrate recruitment (via birth or immigration) can explain the observed stability in stream communities. Drifting macroinvertebrates are often called into question to explain the resistance of stream communities as they can partially offset predation via benthic recruitment, but our results show that stream resistance can be high even where drift is low, i.e., in the outflowing stream.
\end{abstract}

Keywords: Ecological restoration / Salvelinus fontinalis / alpine streams / alpine lakes / drift

Résumé - Les macroinvertébrés alpins se rétablissent-ils différemment dans les lacs et les rivières après l'éradication des poissons exotiques ? Les poissons introduits peuvent avoir des effets néfastes sur le biote indigène vivant dans les eaux douces alpines, et l'ampleur de leur impact dépend de variables telles que les caractéristiques de l'habitat. La présente étude vise à comparer le rétablissement des communautés de macroinvertébrés à la suite d'une campagne d'éradication des poissons dans un lac de montagne (lac Dres, $2087 \mathrm{~m}$ d'altitude, Alpes occidentales italiennes) et ses cours d'eau entrants et sortants. Tous les poissons ont été enlevés par des méthodes mécaniques, sans produire d'effets secondaires pour les macroinvertébrés. Au cours de l'éradication, la communauté lacustre, qui avait été grandement touchée auparavant, s'est rapidement rétablie à des niveaux typiques des lacs n'ayant jamais été empoissonnés. Toutefois, les communautés des cours d'eau n'ont apparemment pas été touchées par les populations de poissons et sont demeurées relativement stables, ce qui prouve leur plus grande capacité à résister à la présence de poissons. L'abondance des refuges spatiaux et le recrutement d'invertébrés (par la naissance ou l'immigration) peuvent expliquer la stabilité observée dans les communautés de rivières. Les macroinvertébrés dérivants sont souvent remis en question pour expliquer la résistance des communautés de cours d'eau, car ils peuvent partiellement compenser la prédation par le recrutement benthique, mais nos résultats montrent que la résistance des cours d'eau peut être élevée même lorsque la dérive est faible, c'est-à-dire dans le cours d'eau aval du lac.

Mots clés : Restauration écologique / Salvelinus fontinalis / ruisseaux alpins / lacs alpins / drift

\footnotetext{
*Corresponding author: rocco.tiberti@gmail.com
} 


\section{Introduction}

Mountain freshwaters are usually isolated from downstream habitats by physical barriers that prevent natural colonization by fish (Adams et al., 2001). In several mountain areas, predatory fish (i.e., trout) have been introduced to promote recreational fishing into originally fishless habitats (Ventura et al., 2017), but their introduction is a serious conservation problem affecting native biota and species (Knapp et al., 2001). Cause for conservation concern lies not only in the magnitude of the local predatory impact, but also in the actual global extent of fish introductions, which involves a substantial number of lakes and rivers over large mountain regions across the planet (Ventura et al., 2017).

Because of the central role played by macroinvertebrates in aquatic habitats, any alteration of their distribution and abundance can indirectly affect entire ecosystems. Aquatic macroinvertebrates have been commonly used as biological indicators of the impact caused by introduced fish, and they have proven to be highly sensitive to fish presence in lakes (Carlisle and Hawkins, 1998; Knapp et al., 2001; Schilling et al., 2009; Tiberti et al., 2014). However, the response of stream communities to introduced fish is subtler and can vary greatly from one study to another (Wooster, 1994; Meissner and Muotka, 2006), being either weak (Allan, 1982; Flecker and Allan, 1984; Reice and Edwards, 1986; Culp, 1986; Ruetz et al., 2004; Cheever and Simon, 2009) or profound (Bechara et al., 1992, 1993; Buria et al., 2007; Rodríguez-Lozano et al., 2015).

The varying levels of ecological impact in rivers and lakes reflect differences in these habitats' ability to withstand introduced fish. There are at least two reasons to explain these differences:

- predatory pressure would be greater in lakes than in rivers. This is due to the density and trophic behavior of fish or the greater availability of spatial refugia against fish predation in streams (e.g., interstices among coarse sediments such as gravel, pebbles and boulders; Bechara et al., 1993);

- macroinvertebrate turnover would be greater in rivers than in lakes with macroinvertebrate production and drifting macroinvertebrates being able to buffer fish predation (Bechara et al., 1993).

The Gran Paradiso National Park (GPNP, Western Italian Alps) recently completed a fish eradication campaign (Tiberti et al., 2019a) with the aim of reducing the negative ecological effects of introduced brook trout (Salvelinus fontinalis, Mitchil 1814) already described in the GPNP lakes (Tiberti and Von Hardenberg, 2012; Magnea et al., 2013; Tiberti et al., 2014). Among the lakes treated for fish eradication, Lake Dres (Fig. 1) is the only one connected to any stream sections permanently inhabited by brook trout, which provides an interesting opportunity to compare the post-eradication recovery in adjacent lotic and lentic habitats. Intensive gill-netting and electrofishing were used as eradication methods without remarkable side effects for aquatic macroinvertebrates and other non-target species (Tiberti et al., 2019a).

The aim of the present study is first to compare the ecological impact of introduced fish on macroinvertebrates (i.e., ecological resistance) and their response to fish

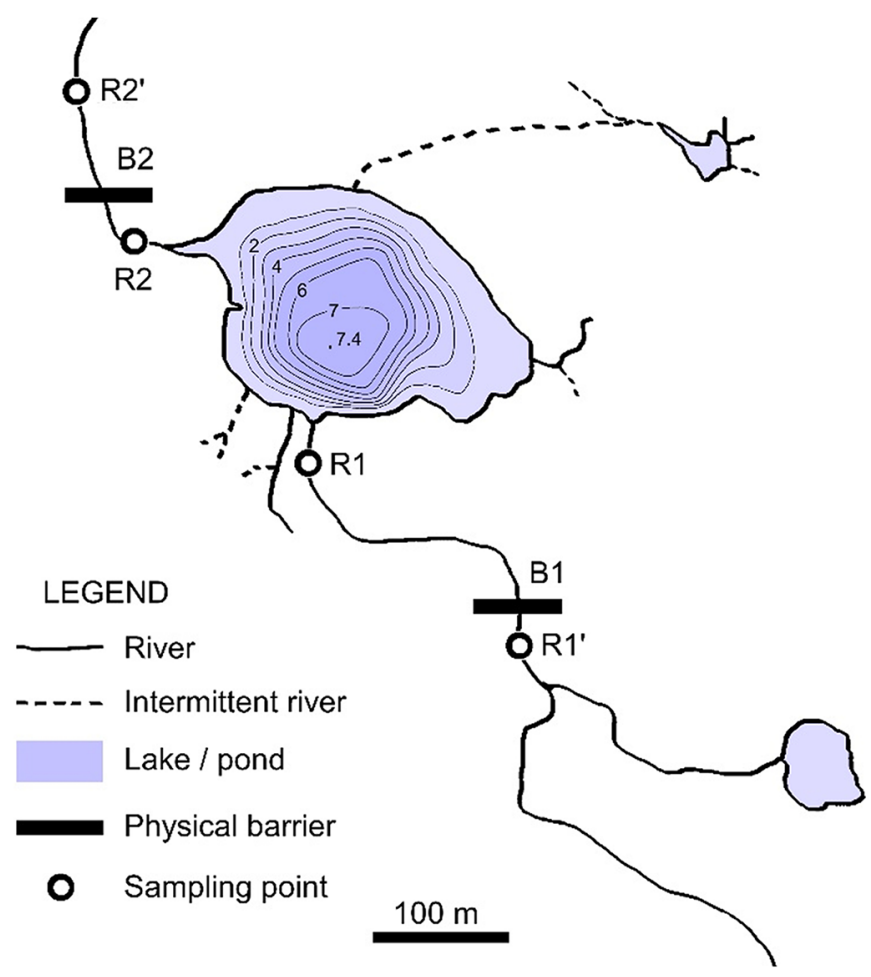

Fig. 1. Study area: Lake Dres (Gran Paradiso National Park, Western Italian Alps) and surrounding aquatic habitats. Water flows in SE-NW direction. Fish eradication involved Lake Dres and the river sections between B1 and B2 (which are waterfalls acting as barriers for upstream fish movements). Fish are naturally absent above B1 and still present downstream B2, which prevent their reinvasion; neither the pond NE of Lake Dres was colonized by brook trout nor was the intermittent river section below it.

eradication (i.e., ecological resilience) in adjacent lentic and lotic (inflowing and outflowing rivers) habitats. Secondly, the study will look at the response of the macroinvertebrates communities above (inflowing river) and below (outflowing river) Lake Dres, as the lake itself disrupts the river continuum and acts as a barrier for drifting organisms. These objectives are based on two hypotheses:

H1: the eradication actions should reverse fish impact (i.e., weak or strong impacts should, respectively, produce minor or major changes in the macroinvertebrate communities following the recovery process).

$\mathrm{H} 2$ : the inflowing river should present higher resistance and resilience compared to the outflowing river, as the macroinvertebrate drift provided by lakes is negligible when compared to that provided by streams.

\section{Methods}

\subsection{Study area and fish population history}

Lake Dres (latitude N $45^{\circ} 24^{\prime} 45^{\prime \prime}$; longitude E $07^{\circ} 13^{\prime} 25^{\prime \prime}$; altitude $2087 \mathrm{~m}$ a.s.l.; surface: 2.6 ha; maximum depth: $7.4 \mathrm{~m}$; Fig. 1) lies at the local timberline and is a typical alpine lake with oligotrophic (mean $\pm S D$ phosphorus concentration $=4.3$ $\pm 2.5 \mu \mathrm{g} \mathrm{L}^{-1} ; N=22$ ), transparent (Photosynthetic Active Radiation attenuation coefficient $-k=0.29 \pm 0.08 ; N=17$ ), 
low conductivity (mean $\pm S D$ conductivity at $20^{\circ} \mathrm{C}=24.9 \pm$ $\left.6.9 \mu \mathrm{S} \mathrm{cm}^{-1} ; N=22\right)$, and circum-neutral $(\mathrm{pH}=7.0 \pm 0.5$; $N=22$ ) waters (measures from a monitoring campaign from 2008 to 2017; Tiberti et al., 2019b). Lake Dres has a single outflowing river (NW of the lake) and several tributaries. Most of them are short, permanent or intermittent spring-fed watercourses, but the main tributary (Rio Dres) is a permanent stream draining a basin of about 290 ha.

Due to the presence of several waterfalls along the outflowing stream, Lake Dres was completely isolated from the downstream fish populations and was originally fishless. Fish stocking history is uncertain, but introductions have probably occurred since the 1960 s, before and after its inclusion in the GPNP territory (1979) and up until the early 2000s when legal disputes concerning the borders of the protected area were finally resolved. Since then, fishing and stocking have been strictly prohibited. After their first introduction, brook trout established a large self-sustaining population.

Fish eradication involved Lake Dres and $380 \mathrm{~m}$ of permanent river sections colonized by brook trout and bordered by two physical barriers (i.e., waterfalls; B1 and B2, Fig. 1) preventing upstream fish dispersion. Introduced fish were eradicated by intensive gillnetting and electrofishing (with an ELT62 II 160 GI backpack equipment) between June 2013 and August 2015 (last fish removed on the 11/08/2015; for detailed methods, see Tiberti et al., 2019a). Previously two intensive rod angling sessions had already enabled a substantial reduction of the initial density of adult fish (Tiberti et al., 2017a).

At the end of the eradication campaign, 15221 fish were removed from the study area: 14560 fish (biomass: $435.7 \mathrm{~kg}$ ) from Lake Dres, 164 fish $(7.1 \mathrm{~kg}$ ) from the inlet (river section between Lake Dres and B1), 668 fish $(24.0 \mathrm{~kg}$ ) from the outlet (river section between Lake Dres and B2), and the remaining 848 fish $(8.1 \mathrm{~kg})$ from the small tributaries (data from Tiberti et al., 2019a).

Based on fish abundance and biomass data, the densities of removed fish are higher than that which is commonly observed in high mountain habitats (Waters, 1977), but comparable among habitats: $0.56 \mathrm{fish} \times \mathrm{m}^{-2}\left(16.69 \mathrm{~g} \times \mathrm{m}^{-2}\right)$ in Lake Dres, 0.15 fish $\times \mathrm{m}^{-2}\left(6.16 \mathrm{~g}^{2} \times \mathrm{m}^{-2}\right)$ in the inflowing river, and $1.78 \mathrm{fish} \times \mathrm{m}^{-2}\left(63.83 \mathrm{~g} \times \mathrm{m}^{-2}\right)$ in the outflowing river. Most fish were removed within one year of the start of the eradication campaign. Thus, the above listed data can be considered as reliable approximations of the fish density/ biomass in the different treated habitats, despite possible fish exchanges between lake and rivers and population recruitment (few reproductive events were recorded in the period 20132015).

\subsection{Macroinvertebrate sampling and analytical methods}

Macroinvertebrate communities were repeatedly sampled during the fish eradication campaign at all of the sampling sites treated for fish eradication, i.e., Lake Dres and two riverine sites (R1 and R2) placed immediately above and below Lake Dres (Fig. 1). Here, macroinvertebrates were sampled 2-3 times per year during the ice-free period, for five consecutive field seasons (2013-2017). The first sample was collected at the beginning of summer (June or July) and the second and the third later in the season (August or September) in order to observe the seasonal variation of the macroinvertebrate communities. R1 and R2 were also sampled in July 2010, providing additional pre-eradication data. Two additional riverine sites placed above $\mathrm{B} 1$ (R1', which is naturally fishless) and below B2 (R2', where fish were not removed) were sampled in August 2016 to provide a reference against which communities of R1 and R2 could be compared

Sampling methods were different in Lake Dres and in the stream sampling sites:

- In Lake Dres, all shore-accessible habitats were sampled for semiquantitative macroinvertebrates estimates. Three littoral microhabitats were chosen according to clast diameter: sand (clast diameter $<2 \mathrm{~mm}$ ), gravel (clast diameter between 2 and $6 \mathrm{~cm}$ ), and boulders (clast diameter $\geq 20 \mathrm{~cm}$ ). In each of these microhabitats, ten sweeps, each about $1 \mathrm{~m}$ long, were conducted with a standard d-frame net (mouth, $25 \times 20 \mathrm{~cm}$; mesh $0.5 \mathrm{~mm}$ ), following Knapp et al. (2001). Lake Dres bottom was dominated by soft muds with the exception of approximately $100 \mathrm{~m}$ of stony bottom extending from the littoral area to up to $4 \mathrm{~m}$ deep in the southern part of the lake. Along with stones, some small patches of gravel were present but fine sediments often obstructed the interstices among stones; most of the northern littoral was covered by a dense belt of emergent aquatic vegetation (i.e., Carex rostrata).

- For streams, semiquantitative macroinvertebrates samples were collected by disturbing the substrate (kick-sampling) with a standard Surber net (area $0.1 \mathrm{~m}^{2}$; mesh $0.5 \mathrm{~mm}$ ) following Barbour et al. (1999) and APAT (2007). A total of 10 sampling units were taken from each sampling site. The 10 sampling units were distributed according to stream bed habitat composition and coverage, i.e., if the stream bottom was $50 \%$ gravel, then 5 sampling units were taken there. Only microhabitats covering at least $10 \%$ of the benthic area were sampled. This procedure results in sampling of approximately $1.00 \mathrm{~m}^{2}$ stream bottom area. Streambed microhabitat composition and coverage were determined by visual inspection at each sampling occasion, accounting for the seasonal variability in substrate composition associated with water level fluctuations: boulders $(>20 \mathrm{~cm}$; mean $\pm \mathrm{SD}$ percent coverage: $34.4 \pm 5.7$ for $\mathrm{R} 1$ and $53.3 \pm 8.7$ for R2), pebbles (6$20 \mathrm{~cm} ; 54.4 \pm 8.8$ for R1 and $33.3 \pm 8.7$ for R2), gravel (2$6 \mathrm{~cm} ; 8.8 \pm 3.3$ for R1 and $5.6 \pm 7.3$ for R2), and aquatic mosses $(2.2 \pm 4.4$ for $\mathrm{R} 1$ and $8.9 \pm 3.3$ for R2) were the most representative substrates, while very small patches of fine sediments were also present. Percent coverage variability in station $\mathrm{R} 1$ and $\mathrm{R} 2$ is due to seasonal fluctuations of water level (flooding different areas).

Macroinvertebrates were sorted in the field and preserved in $70 \%$ ethanol; the keeping of specimens separated from different substrates allowed for comparisons among microhabitats. Specimens were identified using a dissecting stereoscope to the family/genus levels (following Campaioli et al., 1994), which represent our Operational Taxonomic Units (OTUs; see Online Supplementary Material 1 Table S1), 
and grouped into both ecological groups (EG, distinguishing between burrower vs. non-burrower taxa; Knapp et al., 2001; Tiberti et al., 2014) and functional feeding groups (FFG; following autoecological information from freshwaterecology. org, made available online by Schmidt-Kloiber and Hering, 2015, 2018). Each OTU was enumerated and its size distribution was described by body-length measurements. The number of measured specimens per OTU varied between 1 and 350 specimens per sample (mean $\pm \mathrm{SD}=16.6 \pm 33.6$ ); the fact that most OTUs were rare should be taken into consideration when contemplating such a large sample size variability. Individual lengths were converted into dry-mass using equations from literature (Benke et al., 1999; Miserendino, 2001; Baumgärtner and Rothhaupt, 2003; Méthot et al., 2012; Rivera-Usme et al., 2014; see Online Supplementary Material 1 Table S2 for details), in order to calculate the biomass of each OTU, of the functional and ecological groups, and of the entire macroinvertebrate communities.

\subsection{Fish diet and length-weight relationship}

Between 2006 and 2015, 301 brook trout stomachs (214 from Lake Dres and 87 from the lake tributaries) were collected in order to describe the population's summer diet. All stomachs were dissected for prey presence/absence and a subsample of 191 stomachs (132 from Lake Dres and 59 from the lake tributaries) was taken for prey item counting. Stomachs were preserved in $70 \%$ ethanol. Prey items were sorted for counting under a stereomicroscope in the laboratory. A closed counting chamber was used to identify microscopic preys (e.g., zooplankton) under a binocular dissecting microscope at $40 \times$ (Olympus $\mathrm{CH}$ $\mathrm{BI} 45-3)$. Ingested items were divided into aquatic and terrestrial prey, and aquatic macroinvertebrates were classified to the order/ class level. Fragmented or partially digested items were recognized using body parts resistant to digestion (e.g., cephalic capsule) or were recorded as non-identified prey and grouped in a separate category. Dietary data are offered on frequency of occurrence and relative abundance of the prey groups divided by three fish size classes (from 0 to $\geq 20 \mathrm{~cm}$, at $10 \mathrm{~cm}$ size intervals). Most stomach data of fish diet were extracted from Tiberti et al. (2016).

Total length (TL) and body wet weight (W) were measured, respectively, to the nearest $1 \mathrm{~mm}$ and $1 \mathrm{~g}$ on a representative subsample of captured brook trout. Lengthweight relationships and Fulton's condition factor $(\mathrm{K})$ were estimated separately for stream and lake dwelling brook trout.

\subsection{Statistical analyses}

Macroinvertebrate assemblages from Lake Dres, R1 and R2 were ordinated into taxonomic, functional (based on FFG) and ecological (based on EG) matrices of abundance. All statistical analyses were performed using $\mathrm{R}$ version 3.4.3 ( $\mathrm{R}$ Core Team, 2017).

\subsubsection{Community response to fish eradication: multivariate analyses}

The taxonomic matrices from each sampling station ( $\mathrm{Y}_{\mathrm{LAKE}}, \mathrm{Y}_{\mathrm{R} 1}$, and $\mathrm{Y}_{\mathrm{R} 2}$ ) were related to a corresponding matrix of explanatory variables $(\mathrm{X})$ using canonical redundancy analysis (RDA; Mardia et al., 1979) implemented in the package "vegan" (Oksanen et al., 2013) of the statistical environment R 3.4.3 (R Core Team, 2017).

Explanatory variables included:

- microhabitat (MICRO: "sand", "gravel" or "boulders" for lake dwelling macroinvertebrates, and "gravel", "pebbles", "boulders", and "aquatic mosses" for stream-dwelling macroinvertebrates),

- time (TIME in years, as days elapsed from the beginning of the eradication action divided by 365 ),

- season (DAY as days elapsed from the 15th of June of each year).

As recommended by Rao (1995), RDA was performed separately on the Hellinger transformed taxonomic matrices of macroinvertebrate abundances. To perform RDA on $\mathrm{Y}_{\mathrm{R} 1}$, and $Y_{R 2}$ the variation associated to the variable number of replicates in each microhabitat (condition) was partialled out. The function "ordistep" was used to select a set of nonredundant explanatory variables of the structuring of the composition of macroinvertebrate communities. Significance of each explanatory variable was determined using Monte Carlo permutation tests (999 times) on the RDA results. Results of the ordination were displayed in correlation triplots.

\subsubsection{Community response to fish eradication: biodiversity, functional/ecological groups}

Richness $(R)$, Shannon index $(H)$ and inverse Simpson's index $(S)$ were calculated based on the OTU matrices. The macroinvertebrate response to fish eradication was described at each sampling station (Lake Dres, R1 and R2) using (i) linear regression models (LM) for biodiversity indices (dependent variables: $\mathrm{R}, \mathrm{H}$ and $\mathrm{S}$ ) and biomass data of functional feeding and ecological groups, and (ii) generalized linear models (GLM) to count data of functional feeding (FFG) and ecological (EG) groups. Before running LMs, the dependent variables were checked for normality using the Shapiro-Wilk test and all biomass data were $\log +1$ transformed. Poisson GLMs were checked for overdispersion using the "dispersiontest" function in the "AER" package (Kleiber and Zeileis, 2008). Since all GLMs were overdispersed, quasiPoisson models were fitted to the same data. Model covariates were the same used in RDA analysis (TIME, DAY, MICRO). In the GLMs from R1 and R2, the number of replicates in each microhabitat was included as an offset to correct the abundance of functional and ecological groups.

\subsubsection{Lengths and biomasses}

A series of linear regressions were used to test if macroinvertebrate lengths and total biomasses of the communities increased during the monitoring period in Lake Dres, R1, and R2. To obtain an adequate number of observations per taxon, we merged our OTUs into coarser taxonomic groups, including the insect orders, Hydrachnidia, Mollusca, and Oligochaeta. Rare taxa with less than 20 measured individuals or with measurements available for less than three years (i.e., Odonata; Coleoptera, Heteroptera and 
Mollusca in R1 and R2; Ephemeroptera in Lake Dres) were excluded from the body size analysis. Additionally, due to the damage caused by alcohol fixation, we performed very few measures of Platyhelminthes, and these were also therefore excluded from the body size analysis. We added the logtransformed length of the macroinvertebrates belonging to each taxonomic category and the log-transformed total macroinvertebrate biomasses as dependent variables, and the year of sampling - from zero to 5 (year 0 is 2010 and years 1-5 are 2013-2017) - as an independent variable.

\section{Results}

\subsection{Community composition: taxonomic, functional and ecological groups}

A total of 42 different OTUs were identified in the study area. The macroinvertebrate communities differ between standing and running waters, with some OTUs being characteristic and abundant in Lake Dres (e.g., Pisidium, Corixidae, Dytiscidae) and some others in the stream sites (e.g., Ephemeroptera, Simuliidae; Online Supplementary Material 1 Table S1 and Fig. S1). All the riverine sampling sites share most of their OTUs. Sampling sites R1' closely resemble R1 and the same is for R2 and R2' (Online Supplementary Material 1 Table S1 and Fig. S1). All functional feeding groups are present in riverine habitats, but their relative abundance varies among sampling sites (e.g., scrapers are abundant in R1, but rare in R2; Online Supplementary Material 1 Fig. S1). Gathering collectors (e. g., Chironomidae and Oligochaeta) dominate the community in Lake Dres while scrapers (mainly Ephemeroptera) are virtually absent (Online Supplementary Material 1 Fig. S1). Streams have been found to be dominated by non-burrowers. Although burrowers were always dominant in the lake, a strong increase of non-burrowers has been observed during the eradication campaign (see next paragraph).

\subsection{Macroinvertebrate response to fish eradication}

The time elapsed following the beginning of the eradication (TIME) was retained as a significant explanatory variable in RDAs from Lake Dres and R2, suggesting that the communities changed during the eradication campaign. Seasonality (DAY) was retained in all the RDAs, and microhabitat features (MICROHABITAT) in the RDAs from Lake Dres and R2 (Tab. 1).

In particular, triplots show that the abundances of Limnephilidae (Trichoptera) and Corixidae (Heteroptera) are positively, and Chironomidae larvae are negatively associated with TIME in Lake Dres (Fig. 2). In R2, Crenobia alpina (Tricladida) and Leuctra (Plecoptera) are, respectively, positively and negatively associated with TIME (Fig. 2). However, while the retained explanatory variables account for nearly half $(48.6 \%)$ of the total variance in the taxonomic matrix (constrained variance) from Lake Dres, constrained variance accounts for a much smaller proportion of total variance in the taxonomic matrices from R1 (20.1\%) and R2 $(15.7 \%)$. This questions the reliability of the results from both riverine sampling sites. In all cases the first two RDA axes
Table 1. Effects of the explanatory variables chosen for canonical ordination (RDA) by the backward-selection procedure in each sampling station as calculated by the Monte Carlo permutation test (999 permutations).

\begin{tabular}{llll}
\hline & $\lambda$ & $F$ & $P$ \\
\hline Inlet $-\mathbf{R} 1$ & & & \\
Day & 0.022 & 2.44 & $<0.05$ \\
Microhabitat & 0.048 & 1.80 & $<0.05$ \\
Lake Dres & & & \\
Day & 0.034 & 7.19 & $<0.001$ \\
Time & 0.029 & 6.04 & $<0.01$ \\
Microhabitat & 0.077 & 8.06 & $<0.001$ \\
Outlet - R2 & & & \\
Day & 0.033 & 3.60 & $<0.001$ \\
Time & 0.020 & 2.18 & $<0.05$ \\
\hline
\end{tabular}

account for most $(75.8-100 \%)$ of the constrained variance. Permutation tests show that overall RDA results are always significant $(\lambda=0.07, F=1.96, p<0.01$ for $\mathrm{R} 1 ; \lambda=0.14$, $F=7.34, p<0.001$ for Lake Dres; $\lambda=0.05, F=2.89$, $p<0.001$ for $\mathrm{R} 2$ ).

Lacustrine macroinvertebrates underwent a rapid recovery during the eradication campaign. Previously absent/rare nonburrower macroinvertebrates rapidly recolonized Lake Dres (Fig. 3). Their abundance and biomass increase caused both a general significant increase of all the biodiversity indices as well as major changes in the community-partitioning into functional groups (Fig. 4; see Online Supplementary Material 1 Tables S3 and S4 for detailed model outputs). Predators and shredders increased over TIME and filtering collectors decreased (Fig. 4). At the same time, stream dwelling macroinvertebrate communities did not undergo the same changes (Figs. 3 and 4). All taxa were already present at the beginning of the eradication action and neither biodiversity indices nor the abundance and biomass of the ecological groups showed any significant trend over TIME. The only significant change in riverine communities was observed in R2 and limited to the abundance and biomass of a few functional groups (i.e., a significant decrease of shredder abundance and of the biomass of gathering and filtering collectors; Fig. 4). Community data from naturally fishless R1' (Online Supplementary Material 1 Table S1 and Fig. S1) show that non-invaded and invaded habitats (R1, R2, and R2') share most, if not all, of their OTUs.

Significant size increases were only observed in lake dwelling Oligochaeta $(\beta=0.06 ; t=3.39 ; p<0.001)$ and Heteroptera $(\beta=0.28 ; t=5.34 ; p<0.001)$, while the size of the remaining stream and lake dwelling taxa did not undergo any increase during the monitoring period (Online Supplementary Material 1 Fig. S2). Neither increasing biomass trend observed in Lake Dres as the eradication progressed $(\beta=0.23 ; t=1.19$; $\left.p=0.26 ; R^{2}=0.036\right)$, nor the slightly decreasing trends observed in R1 $\left(\beta=-0.10 ; t=1.13 ; p=0.34 ; R^{2}=0.003\right)$ and R2 $\left(\beta=-0.18 ; t=1.26 ; p=0.24 ; R^{2}=0.054\right)$ were significant (Fig. 5). However, it should be noted that the minimum values of the total macroinvertebrate biomass in Lake Dres were recorded at the beginning of the eradication process. 

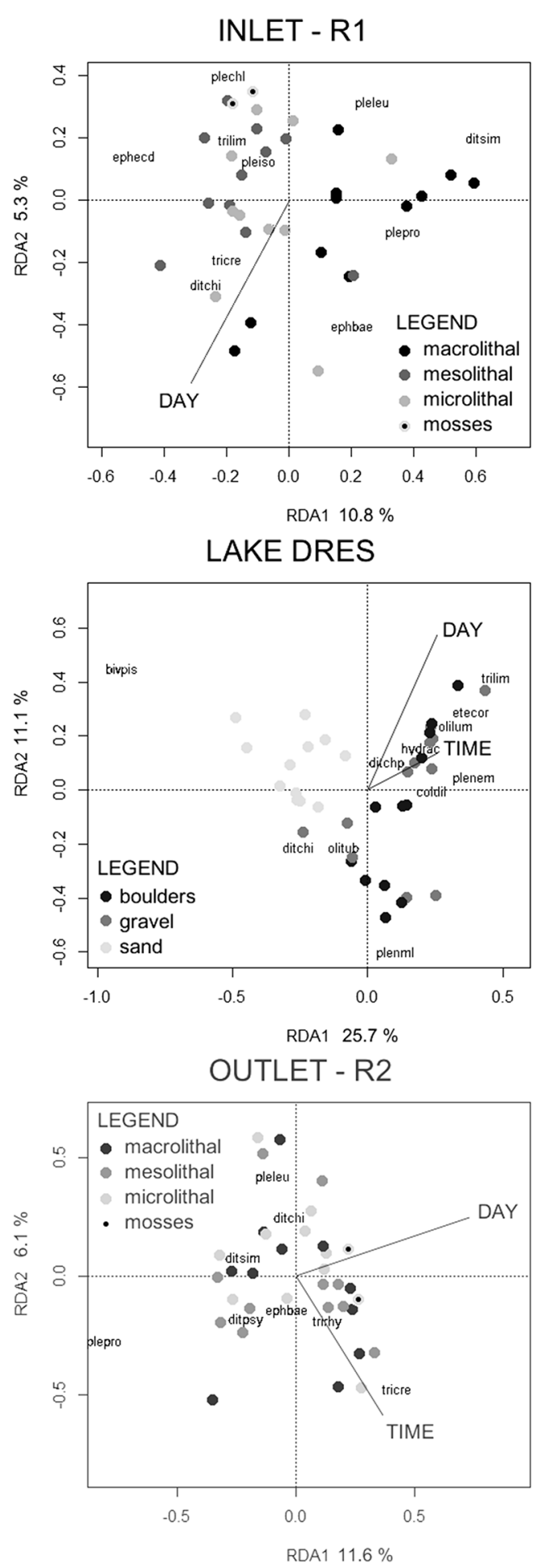

Fig. 2. RDA triplots ordinating the macroinvertebrate samples from Lake Dres, its inlet (R1) and its outlet (R2). Percent values reported along with the RDA axes 1 and 2 indicate the explained proportion of total variance. Black vectors indicate significant explanatory variables retained by the backward selection in each sampling site; most representative macroinvertebrate groups are reported in the diagram with their abbreviated name (abbreviations listed in Tab. 1).

\subsection{Brook trout}

Aquatic macroinvertebrates represent a major part of the diet of stream and lake-dwelling brook trout. Stream-dwelling brook trout consumed larger proportions of non-burrower and conspicuous taxa than brook trout from Lake Dres; Plecoptera, Ephemeroptera, and Trichoptera were present in 63, 24 and $46 \%$ of the stomachs of stream-dwelling brook trout, but only in the $19,<1$ and $15 \%$ of the stomachs of lake-dwelling brook trout. At the same time, fish in Lake Dres rely mainly on Diptera larvae and pupae (almost exclusively Chironomidae) as well as on larger amounts of external resources (terrestrial arthropod subsidies; see Online Supplementary Material 1 Table S5 for a detailed description of brook trout diet).

Compared to the brook trout living in Lake Dres, those living in streams have a greater standard weight and $\mathrm{K}$ (mean \pm SD for lake: $0.94 \pm 0.17$; mean \pm SD for streams: $1.09 \pm 0.19$; Welch Two Sample t-test for mean comparison: $t=-10.95 ; \quad$ df $=266 ; \quad p<0.001 ;$ Online Supplementary Material 1 Fig. S3).

\section{Discussion}

Introduced fish are known to have a considerable predatory impact on the macroinvertebrate communities inhabiting originally fishless mountain lakes (Carlisle and Hawkins, 1998; Knapp et al., 2001; Schilling et al., 2009; Tiberti et al., 2014), reducing the abundance of or extirpating entire ecological groups (epibenthic and nektonic macroinvertebrates), with just a few exceptions (e.g., Zaharescu et al., 2016). At the same time, the impact that introduced fish have on the composition and size structure of stream macroinvertebrates communities can be either lacking or weak (Allan, 1982; Flecker and Allan, 1984; Reice and Edwards, 1986; Culp, 1986; Ruetz et al., 2004; Cheever and Simon, 2009; Nicola et al., 2010), or noticeable and even profound (Bechara et al., 1992, 1993; Buria et al., 2007; RodríguezLozano et al., 2015; see Wooster, 1994 for a review and Meissner and Muotka, 2006 for a meta-analysis).

The present study confirmed the most common patterns reported in literature: introduced fish have a marked impact in lakes (Knapp et al., 2001; Tiberti et al., 2014) whilst their impact is weak in streams (Wooster, 1994; Meissner and Muotka, 2006). For example, macroinvertebrate extirpation occurred in Lake Dres, but not in streams. According to literature and confirming the first hypothesis $\mathrm{H} 1$, the community recovery after fish eradication also followed differing trajectories: lake communities shifted from an impacted state to a new one, which closely resembles that of pristine, never-stocked lakes (Tiberti et al., 2019a) whilst stream communities tended to maintain a more stable composition throughout the eradication process. This relative stability reveals resistance to fish presence rather than unsuccessful recovery, because communities from noninvaded (i.e., R1') and invaded stream sections (i.e. R1, R2, and R2') had similar community biomass and composition in terms of taxonomic, functional and ecological groups as well as in terms of average size. In addition, the communities of R1, $\mathrm{R} 2$, and R2' were also similar (i.e., same dominant OTUs) to the ones found in non-invaded streams in the GPNP 

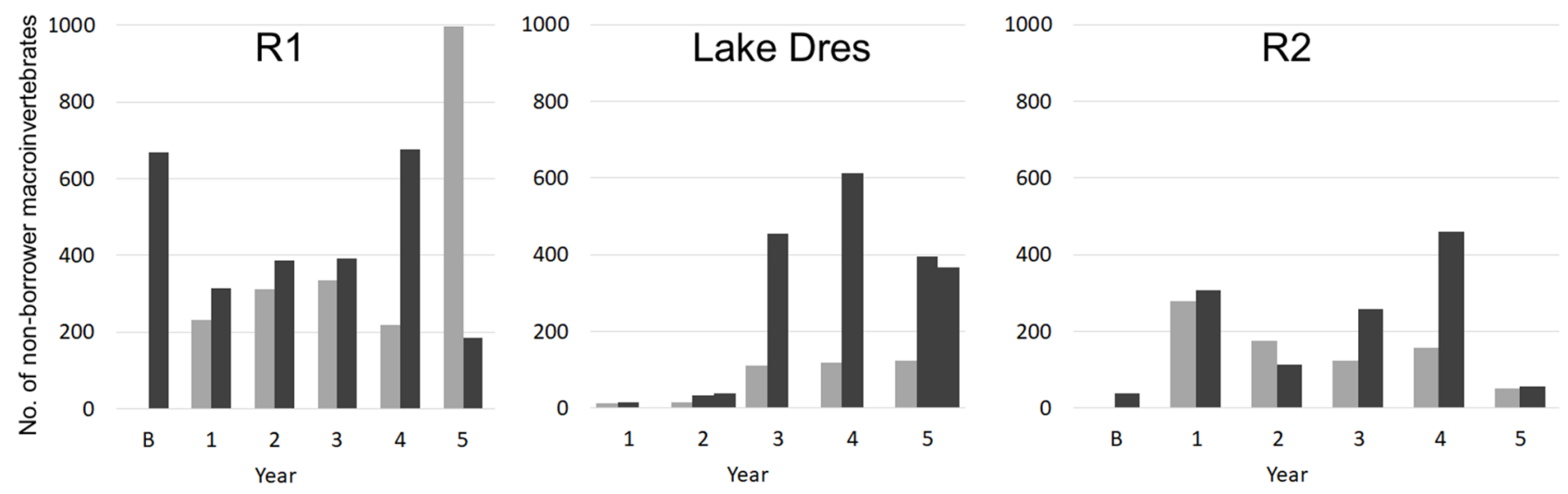

Samples collected in June - July

Samples collected in August - September

Fig. 3. Multiannual trends of non-fossorial macroinvertebrate abundance as measured in the sampling sites R1, Lake Dres and R2 along with a fish eradication action. Grey bars: samples collected early in the summer (June-July); black bars: samples collected late in the summer (AugustSeptember); year: 1-5 correspond to the period 2013-2017, while B indicates samples collected before the beginning of the eradication action (in August 2010).

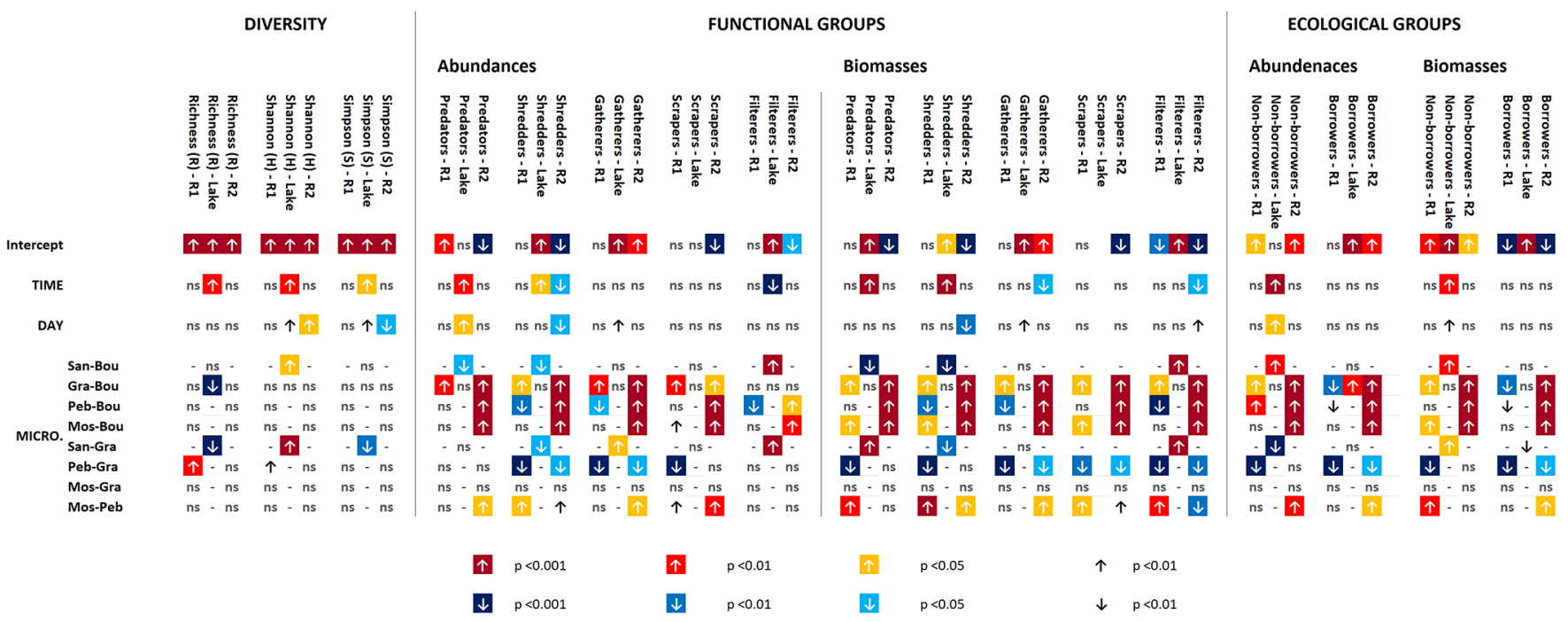

Fig. 4. Graphical summary of the response of diversity indices, macroinvertebrate feeding functional groups and ecological groups during a fish eradication campaign in adjacent lentic and lotic (R1: inflowing river; R2: outflowing river) ecosystems. Up and down arrows, respectively, indicate increasing and decreasing trends associated with different probability levels (i.e., p levels from linear regression models and generalized linear models). MICRO.: microhabitats; San: mud/sand; Bou: boulders; Gra: gravel; Peb: pebbles; Mos: aquatic mosses.

(Piacentini, 2019) and the Alps in general (e.g., Buffagni and Comin, 2000), providing further indirect evidence of the high resistance of stream invertebrates to fish predation.

If our second study hypothesis had been confirmed, R1 should have presented higher resistance than $\mathrm{R} 2$, due to macroinvertebrate immigration (drift) from upstream fishless habitats. Multivariate and univariate analyses suggest that the time elapsed from the beginning of the eradication may have had a significant effect on the macroinvertebrate community of $\mathrm{R} 2$ but not on that of $\mathrm{R} 1$, which is consistent with $\mathrm{H} 2$. This effect was mainly related to a decreased abundance of Leuctra (shredder, Plecoptera) and an increased abundance of Crenobia alpina (predator, Tricladida). However, RDA results from riverine sampling sites should be interpreted with caution (large proportion of unconstrained variance) and the changes in the R2 riverine macroinvertebrate community cannot be clearly linked to fish eradication (e.g., Leuctra is a potential prey for fish, but it decreased after fish eradication). In general, the results collected do not clearly support $\mathrm{H} 2$.

A main result of the present study is that macroinvertebrate resilience after fish removal was much higher in lakes than in rivers, which reflects the higher resistance of riverine communities to fish predation without a clear effect of macroinvertebrate drift. The high resistance in streams (Allan, 1982; Reice, 1991) can be attributable to both low predatory pressure and high macroinvertebrate turnover. Low predatory pressures may occur for at least three reasons: low fish density, macroinvertebrates represent a small fraction of fish diet, or macroinvertebrates are able to escape predation. Macroinvertebrate turnover depends on immigration (i.e., drifting 


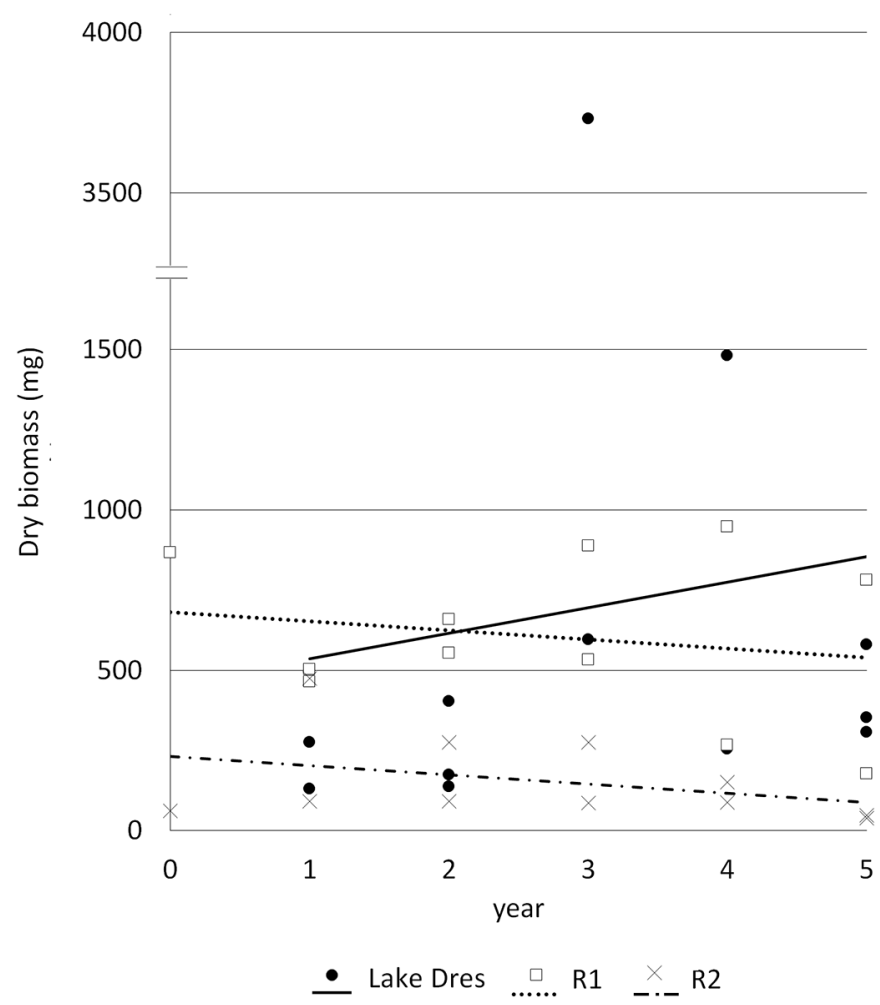

Fig. 5. Macroinvertebrate biomass trends in the sampling sites R1, Lake Dres and R2 along with a fish eradication action.

macroinvertebrates) and recruitment (i.e. macroinvertebrate production).

\subsection{Fish density}

Fish densities were similar and remarkably high both in Lake Dres and in the stream sections (Waters, 1977; Tiberti et al., 2017b). The fact that the recovery of lake dwelling macroinvertebrates started well before the capture of the last fish suggests that fish impact is density dependent. However, brook trout are also likely to continue having an impact on macroinvertebrates when fish density is low, as the impact of brook trout in Lake Dres was almost the same as in other high mountain lakes with markedly lower fish densities (Tiberti et al., 2019a). In streams, the macroinvertebrate communities remained stable despite the reduction in fish density, as had already been observed by Allan (1982), Twomey and Giller (1991), and Reice (1991). Independent dynamics in predatorprey (fish-macroinvertebrates) systems may be an underlying factor in habitat, rather than prey limitation, in particular when prey production and turnover is able to buffer predation (Giller and Malmqvist, 1998; see next paragraphs).

\subsection{Macroinvertebrate consumption}

Both stream and lake dwelling fish rely on aquatic macroinvertebrates as an important food resource. As stomach contents of stream dwelling fish revealed high levels of consumption of a few taxa of aquatic insects (e.g., Trichoptera, Ephemeroptera, and Plecoptera), much higher than in the case of lake dwelling trout, the fact that stream macroinvertebrate did not increase after trout removal was unexpected.

Brook trout is an opportunistic predator (Lacasse and Magnan, 1992) and most of the differences between the diet of stream and lake dwelling populations should be ascribed to prey availability (Tiberti et al., 2016). On the one hand, brook trout introduction in lakes causes the extinction of nonburrower taxa, which then becomes unavailable as a food resource. On the other hand, fish in streams do not cause the extinction of benthic taxa where they continue to be available as food. The diet of brook trout is therefore likely a consequence rather than an explanation of the different levels of resistance of lake and stream macroinvertebrates.

\subsection{Escaping predation}

Macroinvertebrates can escape predation thanks to an array of antipredator adaptations, including morphological, physiological (e.g., unpalatable secretions) and behavioral adaptations. The observed results suggest that whatever the most effective antipredator mechanism is, it may be more effective for stream than for lake communities, as some shared taxa (several genera of Plecoptera and Trichoptera) were impacted in Lake Dres but not in rivers. Habitat features can influence the effectiveness of the antipredator strategies mentioned above. In particular, the availability of spatial refugia (i.e., interstices between clasts) and fish free areas (i.e. fast flowing areas such as some riffles) can reduce predatory pressure and enhance macroinvertebrate resistance (Bechara et al., 1993). Both interstices and fish free areas are less abundant in lakes, where fine sediments dominate the bottom and occupy the interstices among coarse sediments.

\subsection{Macroinvertebrate turnover}

High levels of immigration and production can enhance macroinvertebrate turnover and buffer the impact of introduced fish. A mechanism which can provide large amounts of immigrants in running waters, but not in lakes, is drift (Allan, 1982). In the present study, Lake Dres disrupts the river continuum so that R2 cannot be supplied by drifting organisms from upstream riverine habitats. As mentioned above, stream macroinvertebrates seem to be able to withstand predatory pressure without the need for immigrants and drift should therefore be excluded as the main determinant of the high resistance of stream macroinvertebrates. A further factor which would enhance macroinvertebrate turnover is local macroinvertebrate production. The observed resistance of the riverine macroinvertebrates could be explained if macroinvertebrate production is higher than fish consumption, but a few existing estimates of macroinvertebrate production in mountain streams (e.g., $0.65-1.9 \mathrm{~g} \mathrm{~m}^{-2} \mathrm{yr}^{-1}$ dry weight; Buffagni and Comin, 2000) and lakes (e.g., dry mass production: $1.5-1.8 \mathrm{~g} \mathrm{~m}^{-2} \mathrm{yr}^{-1}$; Detmer et al., 2017) from the temperate regions show quite similar values and the results of this study showed that stream dwelling brook trout consume larger amounts of macroinvertebrates than their lake-dwelling counterparts. The fact that macroinvertebrates and fish densities are independent i.e., stream macroinvertebrate abundance did not change when fish density was reduced, 
suggests that stream dwelling fish are not limited by nutrition, although they are possibly habitat-limited (Giller and Malmqvist, 1998). Indirect proof of this mechanism can be observed in the more favorable trophic conditions of stream dwelling brook trout, compared to lake dwelling ones, as demonstrated by the standard weight equations (Online Supplementary Material 1 Fig. S3). Under conditions of superabundant prey resources, it is unlikely that a generalist predator - such as brook trout (Lacasse and Magnan, 1992) would influence the prey community. Prey limitation has been recognized as a potentially limiting factor for stream dwelling fish (e.g., Salmo trutta; Gíslason, 1994), but in most cases predators do not rely completely on a single type of prey so that their correlation with preys can be weak or absent (Giller and Malmqvist, 1998).

In conclusion, macroinvertebrates confirmed to be very good biological indicators of the local impact of introduced fish in mountain lakes (Schilling et al., 2009). Their communities are indeed sensitive to both fish introduction i.e., low resistance and fish removal i.e., high resilience. Their response to fish eradication is clearly linked to the community recovery from a series of direct and indirect impacts involving the entire lake ecosystem (Knapp et al., 2001; Tiberti et al., 2019a). Although macroinvertebrates are highly resistant to fish introduction in streams (present study; Wooster 1994), fish are known to affect the integrity of alpine rivers in a variety of other ways, e.g., affecting native semiaquatic vertebrates (Bosch et al., 2006, 2019) and fish populations (Ross, 1991; Dunham et al., 2002), nutrient cycles and ecological connection with riparian habitats (Alexiades et al., 2017). Macroinvertebrate recruitments and the availability of spatial refugia could provide potential explanations for the high resistance of stream macroinvertebrates, which is consistently high, even when drift is low (i.e., outflowing river). Drift is considered very important in determining macroinvertebrates' resistance to fish predation, but our results question the generality of this assumption and, in general, the efficacy of macroinvertebrates as good bioindicators of the impact of introduced fish in mountain streams. A better taxonomic detail and more extensive studies could provide better indications on subtler impacts. However, a fundamental characteristic of 'good bioindicators' is the possibility to perform easy and cheap surveys; the need to increase the taxonomic detail would make surveys more timeexpensive and put into question the convenience of using macroinvertebrates as bioindicators, in particular in large monitoring studies.

\section{Supplementary Material}

Supplementary Tables.

The Supplementary Material is available at https:/www.kmaejournal.org/10.1051/kmae/2018040/olm.

Acknowledgements. The authors would like to thank Bruno Bassano, Achaz von Hardenberg, Ramona Viterbi (GPNP) and Giuseppe Bogliani (University of Pavia) for their commitment to research in the GPNP. Special thanks go to the park wardens for their help and hospitality, and to several students and field assistants for their help during the fieldwork. We thank Laura Bohin for her kind linguistic revision. Funding and logistic support for this research was provided by the Gran Paradiso National Park within the framework of the LIFE+ project BIOAQUAE (Biodiversity Improvement of Aquatic Alpine Ecosystems; LIFE11 BIO/ IT/ 000020), and by the University of Pavia (Grant Number 105355 issued to Rocco Tiberti). Permissions for fishing activities were issued by the GPNP (protocol number 1798/ 1013/BB) with the approval of ISPRA (Istituto Superiore per la Protezione e Ricerca Ambientale, protocol number 0017655 - 29/04/2013).

\section{References}

Adams SB, Frissell CA, Rieman BE. 2001. Geography of invasion in mountain streams: consequences of headwater lake fish introductions. Ecosystems 4: 296-307.

Alexiades AV, Flecker AS, Kraft CE. 2017. Nonnative fish stocking alters stream ecosystem nutrient dynamics. Ecol Appl 27: 956-965.

Allan JD. 1982. The effect of reduction of trout density on the invertebrate community of a mountain stream. Ecology 63: $1444-1455$.

APAT. 2007. Metodi biologici per le acque. Parte I. APAT, Rome, Italy, 300 p. (in Italian)

Barbour MT, Gerritsen J, Snyder BD, Stribling JB. 1999. Rapid bioassessment protocols for use in streams and wadeable rivers: periphyton, benthic macroinvertebrates, and Fish, 2nd ed. Report number EPA 841-B-99-002. US EPA, Washington, US, 337 p.

Baumgärtner D, Rothhaupt KO. 2003. Predictive length-dry mass regressions for freshwater invertebrates in a pre-alpine lake littoral. Int Rev Hydrobiol 88: 453-463.

Bechara JA, Moreau G, Planas D. 1992. Top-down effects of brook trout (Salvelinus fontinalis) in a boreal forest stream. Can J Fish Aquat Sci 49: 2093-2103.

Bechara JA, Moreau G, Hare L. 1993. The impact of brook trout (Salvelinus fontinalis) on an experimental stream benthic community: the role of spatial and size refugia. J Anim Ecol 62: 451-464.

Benke AC, Huryn AD, Smock LA, Wallace JB. 1999. Length-mass relationships for freshwater macroinvertebrates in North America with particular reference to the southeastern United States. J North Am Benthol Soc 18: 308-343.

Bosch J, Rincon PA, Boyero L, Martínez-Solano I. 2006. Effects of introduced salmonids on a montane population of Iberian frogs. Conserv Biol 20: 180-189.

Bosch J, Bielby J, Martin-Beyer B, Rincón P, Correa-Araneda F, Boyero L. 2019. Eradication of introduced fish allows successful recovery of a stream-dwelling amphibian. PloS One 14: e0216204.

Buffagni A, Comin E. 2000. Secondary production of benthic communities at the habitat scale as a tool to assess ecological integrity in mountain streams. In Shmutz S, ed. Assessing the Ecological Integrity of Running Waters: Proceedings of the International Conference, Vienna, Austria, 9-11 November 1998. Dordrecht: Springer Science \& Business Media, pp. 183-195.

Buria L, Albariño R, Villanueva VD, Modenutti B, Balseiro E. 2007. Impact of exotic rainbow trout on the benthic macroinvertebrate community from Andean-Patagonian headwater streams. Fundam Appl Limnol 168: 145-154.

Campaioli S, Ghetti PF, Minelli A. 1994. Manuale per il riconoscimento dei macroinvertebrati delle acque dolci italiane. Trento: Provincia autonoma di Trento, 483 p. (in Italian). 
Carlisle DM, Hawkins CP. 1998. Relationships between invertebrate assemblage structure, 2 trout species, and habitat structure in Utah mountain lakes. J North Am Benthol Soc 17: 286-300.

Cheever BM, Simon KS. 2009. Seasonal influence of brook trout and mottled sculpin on lower trophic levels in an Appalachian stream. Freshw Biol 54: 524-535.

Culp JM. 1986. Experimental evidence that stream macroinvertebrate community structure is unaffected by different densities of coho salmon fry. J North Am Benthol Soc 5: 140-149.

Detmer TM, McCutchan Jr JH, Lewis Jr WM. 2017. Predator driven changes in prey size distribution stabilize secondary production in lacustrine food webs. Limnol Oceanogr 62: 592-605.

Dunham JB, Adams SB, Schroeter RE, Novinger DC. 2002. Alien invasions in aquatic ecosystems: toward an understanding of brook trout invasions and potential impacts on inland cutthroat trout in western North America. Rev Fish Biol Fish 12: 373-391.

Flecker AS, Allan JD. 1984. The importance of predation, substrate and spatial refuge in determining lotic insect distributions. Oecologia 64: 306-313.

Giller PS, Malmqvist B. 1998. The biology of streams and rivers. Oxford: Oxford University Press, 304 p.

Gíslason GM. 1994. River management in cold regions: a case study of the River Laxa, north Iceland. In Calow P, Petts E eds. The rivers handbook: Hydrological and ecological principles, Vol. 2. Oxford: Blackwell Scientific Publications, pp: 464-483.

Kleiber C, Zeileis A. 2008. Applied econometrics with R. New York: Springer-Verlag, $222 \mathrm{p}$

Knapp RA, Matthews KR, Sarnelle O. 2001. Resistance and resilience of alpine lake fauna to fish introductions. Ecol Monogr 71: 401-421.

Lacasse S, Magnan P. 1992. Biotic and abiotic determinants of the diet of brook trout, Salvelinus fontinalis, in lakes of the Laurentian Shield. Can J Fisher Aquat Sci 49: 1001-1009.

Llja K, Šporka F, Štefková E, Tirjaková E, Bitušík P, Bulánková E, Lukáš J, Illéšová D, Derka T, Tomajka J. 2006. Ecological study of a high-mountain stream ecosystem (Hincov potok, High Tatra Mountains, Slovakia). Acta Soc Zool Bohem 69: 299-316.

Magnea U, Sciascia R, Paparella F, Tiberti R, Provenzale A. 2013. A model for high-altitude alpine lake ecosystems and the effect of introduced fish. Ecol Model 251: 211-220.

Mardia KV, Kent JT, Bibby JM. 1979. Multivariate analysis. London: Academic Press, 518 p.

Meissner K, Muotka T. 2006. The role of trout in stream food webs: integrating evidence from field surveys and experiments. $J$ Anim Ecol 75: 421-433.

Méthot G, Hudon C, Gagnon P, Pinel-Alloul B, Armellin A, Tourville AM. 2012. Macroinvertebrate size-mass relationships: how specific should they be? Poirier Freshw Sci 31: 750-764.

Miserendino ML. 2001. Length-mass relationships for macroinvertebrates in freshwater environments of Patagonia (Argentina). Ecología Austral 11: 3-8.

Nicola GG, Almodóvar A, Elvira B. 2010. Effects of environmental factors and predation on benthic communities in headwater streams. Aquatic Sciences 72: 419-429.

Oksanen J, Blanchet FG, Friendly M, Kindt R, Legendre P, McGlinn D, Minchin PR, O'hara RB, Simpson GL, Solymos P, Stevens MHH, Szoecs E, Wagner H. 2013. Package 'vegan'. Community ecology package, version, 2 (9).

Piacentini E. 2019. Analisi dell'impatto dei bacini idroelettrici sulle comunità di macroinvertebrati bentonici degli ecosistemi acquatici montani. B. Sc. dissertation, University of Pavia, Italy (in Italian).

R Core Team 2017. R: A language and environment for statistical computing. R Foundation for Statistical Computing, Vienna, Austria. https://www.R-project.org/ (accessed January 15, 2018).
Rao CR. 1995. A review of canonical coordinates and an alternative to correspondence analysis using Hellinger distance. Qüestiió 19: 23-63.

Reice SR. 1991. Effects of detritus loading and fish predation on leafpack breakdown and benthic macroinvertebrates in a woodland stream. J North Am Benthol Soc 10: 42-56.

Reice SR, Edwards RL. 1986. The effect of vertebrate predation on lotic macroinvertebrate communities in Quebec, Canada. Can J Zool 64: 1930-1936.

Rivera-Usme JJ, Pinilla-Agudelo GA, Camacho-Pinzón DL, CastroRebolledo MI, Rangel-Churio JO. 2014. Length-mass relationships in the aquatic invertebrate genera Helobdella (Hirudinea: Glossiphoniidae) and Asellus (Crustacea: Asellidae) of an Andean wetland of Colombia. Actualidades Biológicas 36: 39-45.

Rodríguez-Lozano P, Verkaik I, Rieradevall M, Prat N. 2015. Small but powerful: top predator local extinction affects ecosystem structure and function in an intermittent stream. PloS One 10: e0117630.

Ross ST. 1991. Mechanisms structuring stream fish assemblages: are there lessons from introduced species? Environ Biol Fish 30: $359-368$.

Ruetz CR, Vondracek B, Newman RM, 2004. Weak top-down control of grazers and periphyton by slimy sculpins in a coldwater stream. $J$ North Am Benthol Soc 23: 271-286.

Schilling EG, Loftin CS, Huryn AD. 2009. Macroinvertebrates as indicators of fish absence in naturally fishless lakes. Freshw Biol 54: 181-202.

Schmidt-Kloiber A, Hering D. 2015. www.freshwaterecology.info an online tool that unifies, standardises and codifies more than 20,000 European freshwater organisms and their ecological preferences. Ecol Indic 53: 271-282.

Schmidt-Kloiber A, Hering D. 2018. www.freshwaterecology.info the taxa and autecology database for freshwater organisms, version 7.0. www.freshwaterecology.info (accessed on April 18, 2018).

Tiberti R, Von Hardenberg A. 2012. Impact of introduced fish on common frog (Rana temporaria) close to its altitudinal limit in alpine lakes. Amphibia-Reptilia 33: 303-307.

Tiberti R, von Hardenberg A, Bogliani G. 2014. Ecological impact of introduced fish in high altitude lakes: a case of study from the European Alps. Hydrobiologia 724: 1-19.

Tiberti R, Brighenti S, Canedoli C, Iacobuzio R, Rolla M. 2016. The diet of introduced brook trout (Salvelinus fontinalis; Mitchill, 1814) in an alpine area and a literature review on its feeding ecology. J Limnol 75: 488-507.

Tiberti R, Ottino M, Brighenti S, Iacobuzio R, Rolla M, Von Hardenberg A, Bassan B. 2017a. Involvement of recreational anglers in the eradication of alien brook trout from alpine lakes. $J$ Mount Ecol 10: 13-26.

Tiberti R, Nelli L, Brighenti S, Iacobuzio R, Rolla M. 2017b. Spatial distribution of introduced brook trout Salvelinus fontinalis (Salmonidae) within alpine lakes: evidences from a fish eradication campaign. Eur Zool J 84: 73-88.

Tiberti R, Bogliani G, Brighenti S, Iacobuzio R, Liautaud K, Rolla M, Von Hardenberg A, Bassano B. 2019a. Recovery of high mountain Alpine lakes after the eradication of introduced brook trout Salvelinus fontinalis using non-chemical methods. Biol Invasion 21: 875-894.

Tiberti R, Nelli L, Marchetto A, Tartari G, Wienckowski E, Rogora M. 2019b. Multi-year trends and determinants of the hydrochemistry of high mountain lakes in the Western Italian Alps. Aquat Sci, submitted.

Twomey H, Giller PS. 1991. The effects of catastrophic flooding on the benthos and fish of a tributary of the River Araglin, Co. Cork. 
R. Tiberti and S. Brighenti: Knowl. Manag. Aquat. Ecosyst. 2019, 420, 37

In Steer MW ed. Irish rivers: biology and management. Dublin: Royal Fish Academy, pp. 47-58.

Ventura M, Tiberti R, Buchaca T, Buñay D, Sabás I, Miró A. 2017. Why should we preserve fishless high mountain lakes. In Catalan J, Ninot JM, Aniz Montes M eds. High mountain conservation in a changing world. Advances in Global Change Researches, Vol. 62. Cham: Springer, pp. 181-205.
Waters TF. 1977. Secondary production in inland waters. $A d v$ Ecol Res 10: 91-164.

Wooster D. 1994. Predator impacts on stream benthic prey. Oecologia 99: 7-15.

Zaharescu DG, Burghelea CI, Hooda PS, Lester RN, Palanca-Soler A. 2016. Small lakes in big landscape: multi-scale drivers of littoral ecosystem in alpine lakes. Sci Total Environ 551: 496-505.

Cite this article as: Tiberti R, Brighenti S. 2019. Do alpine macroinvertebrates recover differently in lakes and rivers after alien fish eradication? Knowl. Manag. Aquat. Ecosyst., 420, 37 